\title{
RUTILE NANORODS: SYNTHESIS, STRUCTURE AND ELECTROCHEMICAL PROPERTIES
}

\author{
V.O. KOTSYUBYNSKY, I.F. MYRONYUK, V.L. CHELYADYN, V.V. MOKLYAK
}

\begin{abstract}
Nanodispersed rutile with rod-like particles was synthesized by hydrolysis of $\mathrm{TiCl}_{4}$ in hydrochloric acid - ethanol alcohol aqueous solution at $40^{\circ} \mathrm{C}$. It was found that the specific surface area, crystallite size, degree of agglomeration are determined by molar ratios of ethanol. The obtained material was used as the base of cathode composition for lithium power sources. The maximum values of specific capacity $(250 \mathrm{mAh} / \mathrm{g})$ at discharge in galvanostatic conditions are fixed in the case of using material with the maximum agglomeration degree and minimal particle size. Phasic character of $\mathrm{Li}^{+}$ions intercalation is set and the diffusion coefficient at different stages of the process is calculated.
\end{abstract}

Keywords: rutile, crystal structure, lithium intercalation, impedance spectroscopy.

\section{INTRODUCTION}

Using metal oxides nanodispersed forms as the cathode material is one of the most advanced ways of improving specific energy characteristics of lithium power sources. An increase of capacity for nanostructured cathode materials is caused by the improving of $\mathrm{Li}^{+}$ions intercalation efficiency as a result of $\mathrm{Li}^{+}$and electrons ions transport path lengths reduction, contact area host-material / electrolyte enlarging, specific surface area and chemical activity of cathode component growing. Crystal structure, surface morphology and electric characteristics of nanodispersed materials are determined by the peculiarities of synthesis, so the possibility of the materials formation with foreseen optimized characteristics is opening. Lithium ion intercalation degree in microcrystal rutile is negligible at room temperature and even for low current densities (C/300) it has kinetic restrictions (Hu et al., 2006). The aim of this paper is to test of nanodispersed rutile for Li-ion electrochemical insertion.

\section{EXPERIMENT}

Rutile $\mathrm{TiO}_{2}$ was synthesized by hydrolysis of $\mathrm{TiCl}_{4}$ in hydrochloric acid - ethanol aqueous solution at $40^{\circ} \mathrm{C}$. It is known that ethanol is very important in the formation of rutile surface morphology. During the reaction at the conditions of high acidity the formation of 6 -fold coordinated complex species $\left[\mathrm{Ti}(\mathrm{OH})_{n} \mathrm{Cl}_{m}\left(\mathrm{OC}_{2} \mathrm{H}_{5}\right)_{6-n-m}\right]^{2-}$ took place where the $\left[\mathrm{OC}_{2} \mathrm{H}_{5}{ }^{-}\right]$served as a retarding factor for the hydrolysis of $\mathrm{TiCl}_{4}$ (Wang et al., 2007). Low number of $\mathrm{OH}$ ligands causes the vertex-shared bonding of [TiO6] octahedra that results in the formation of a rutile phase. The obtained gel $\mathrm{TiO}_{2} \cdot \mathrm{H}_{2} \mathrm{O}$ was set to age for 3 hours at $40^{\circ} \mathrm{C}$. Colloidal solution of $\mathrm{TiO}_{2}$ was kept for 240 hours at $18^{\circ} \mathrm{C}$. After segregation the 
material was dried for 3 hours at $150^{\circ} \mathrm{C}$. The three systems were synthesized for which the ethanol content in the reaction medium was $0,10,20$ and 30 vol. \% respectively.

\section{RESUlts}

Accordingly to the XRD data the system were monophase rutile (Fig. 1, Tab. 1) with rod-like particles. For all obtained materials coherent scattering regions have an ellipsoidal form with the main axis oriented along [001] crystallography direction. System №2 (ethanol content 10 vol. \%) has the minimal size of coherent scattering regions $(9 \times 3 \mathrm{~nm})$, for other systems these sizes are about $12 \times 5 \mathrm{~nm}$. The agglomeration degree depends on the ethanol content at synthesis (Fig. 2). Maximum is the average size of agglomerates for system №2 (500-600 nm), whereas for systems 1 and 3 the size of agglomerates is $150-200 \mathrm{~nm}$. For these systems the size of individual rod-like particles is close to the size of coherent scattering regions, suggesting that their state is close to monocrystal.

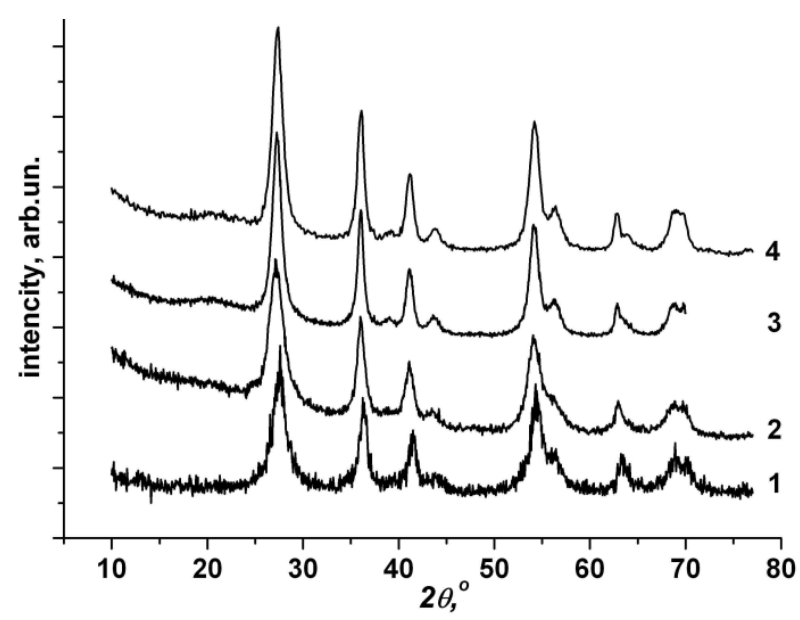

Fig. 1. XRD patterns of rutile obtained for different ethanol content (1- 0 vol. \%, 2-10 vol. \%, 3-20 vol. \% 4-30 vol. \%)

\begin{tabular}{|c|c|c|c|c|c|c|}
\hline \multirow{2}{*}{ System } & \multirow{2}{*}{$\begin{array}{c}\text { Etanol } \\
\text { content, } \\
\text { vol. } \%\end{array}$} & \multicolumn{2}{|c|}{ Lattice parameters } & \multirow{2}{*}{$\begin{array}{l}\text { Average size of } \\
\text { coherent } \\
\text { scattering } \\
\text { regions, nm }\end{array}$} & \multirow{2}{*}{$\begin{array}{l}\text { Specific } \\
\text { surface } \\
\text { area, } \mathrm{m}^{2} / \mathrm{g}\end{array}$} & \multirow{2}{*}{$\begin{array}{c}\text { Mass loss } \\
\text { (annealing up } \\
\text { to } 1000^{\circ} \mathrm{C} \text { ), \% }\end{array}$} \\
\hline & & $a, \mathrm{~nm}$ & $c, \mathrm{~nm}$ & & & \\
\hline 1 & 0 & 4.6223 & 2.9488 & $12 \times 4$ & 165 & 15.8 \\
\hline 2 & 10 & 4.6286 & 2.9539 & $9 \times 3$ & 77 & 6.7 \\
\hline 3 & 20 & 4.6143 & 2.9538 & $12 \times 6$ & 90 & 7.7 \\
\hline 4 & 30 & 4.6072 & 2.9575 & $12 \times 4$ & 106 & 11.4 \\
\hline
\end{tabular}

Tab. 1. Structure and morphology characteristics of obtained rutile

The rutile particles of system 4 are weakly aggregated and have linear sizes 20-70 $\mathrm{nm}$ at diameter 10 $\mathrm{nm}$ and they are polycrystalline formations. Fixed values of specific surface area reflected changes in the morphology of obtained materials. Loss of weight at heating is explained by desorption of surface hydroxyl groups, as evidenced by fixed for all materials a clear linear dependence between mass loss and the value of specific surface area (Tab. 1). 

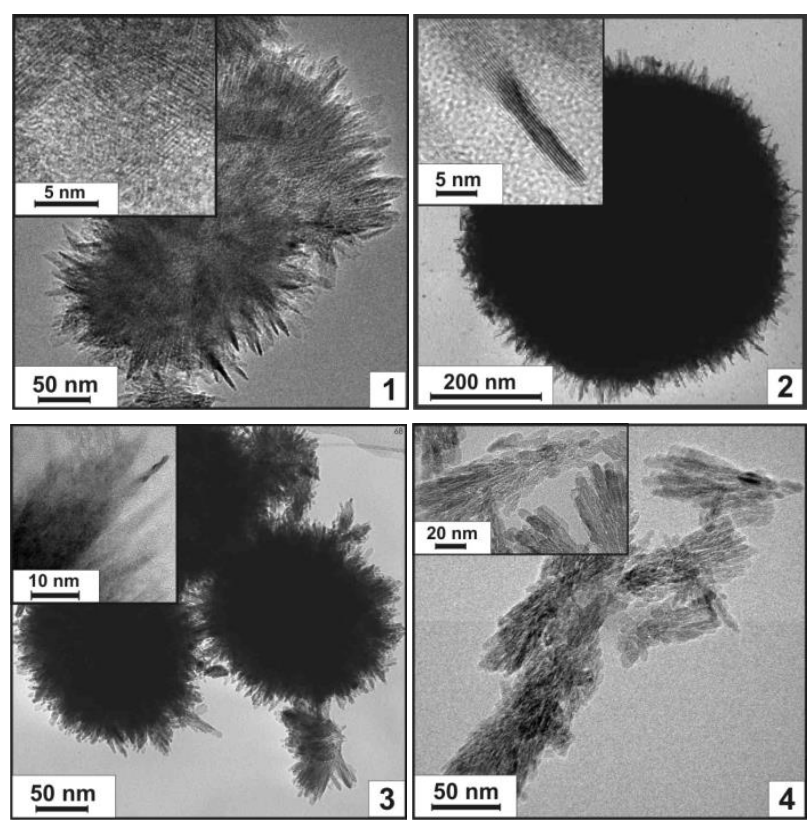

Fig. 2. TEM images of rutile synthesized for different ethanol content (1- 0 vol. \%, 2- 10 vol. \%, 3-20 vol. \% 4-30 vol. \%)

For checking a possible presence in the material of X-ray amorphous phases of anatase or brookite all the obtained materials were annealed for $1 \mathrm{~h}$ at temperatures of 400 and $600^{\circ} \mathrm{C}$. Additional phases were not observed. Annealing the materials at $400^{\circ} \mathrm{C}$ initiated the process of particles growing with the major axis orientation been saved.

The obtained material was used as a base of the cathode for model lithium power sources (LPS). Cathode composition contains obtained rutile (90 mass \%) acetylene black ( 8 mass \%) and PVF (2 mass $\%)$. The discharge of LPS was carried out in galvanostatic conditions at current density of C/100. The kinetics of the discharge process was studied by measuring an open circuit voltage (OCV) with the use of a three-electrode scheme. Polarizing and comparison electrodes were made from lithium foil; a working electrode was nickel mesh with the pressed film of cathode composition. $1 \mathrm{M}$ of $\mathrm{LiBF}_{4} \gamma$ butyrolactone was used as an electrolyte. The degree of intercalation $x$ was calculated as the molar amount of $\mathrm{Li}+$ ions transferred through electrolyte per one mole of titanium dioxide in the cathode composition. A character of discharge curve (Fig. 3) is the result of different processes domination at different stages of discharge: intercalation into the rutile structure, formation of a double electric layer on its surface, a change of material phase composition.

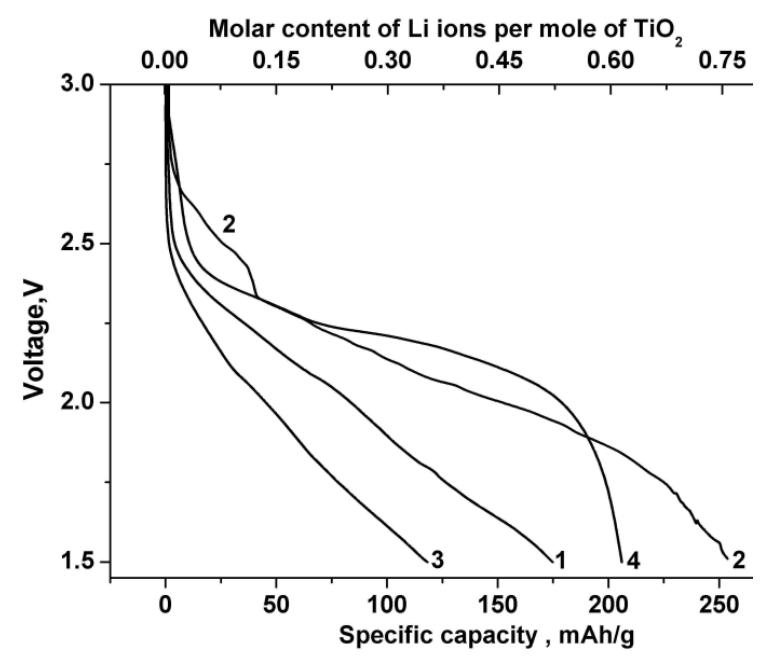

Fig. 3. The discharge curves of the LPS with the cathode based on rutile from different system 
Frequency dispersion of complex impedance was studied in the range of $10^{-2}-10^{5} \mathrm{~Hz}$. Based on the impedance-spectroscopic data three stages were found out, which correspond to ranges of the intercalation degree $0<x \leq 0.2 ; 0.3 \leq x \leq 0.45$ and $0.55 \leq x \leq 0.75$ respectively. The first stage is characterized by a sharp decrease of the OCV caused by the $\mathrm{Li}^{+}$ions localization on the particle surface with the following intercalation into crystal structure. The localization of $\mathrm{Li}^{+}$ions is the most probable in the octahedral oxygen vacancies, as well as in the structural channels [001], and the emergence of pair interaction between intercalated lithium ions in the plain (110) can lead to the blockage of the channel and serve as a barrier to subsequent introduction. High specific surface area of the nanodispersed rutile increases the number of channels opened for $\mathrm{Li}^{+}$intercalation and neutralizes the influence of their blocking. The other advantage is the possibility of $\mathrm{Li}^{+}$ions localization in the form of the sorption layer on the surface of cathode materials. The equivalent scheme (Fig. 4) was used for fitting the Nyquist diagrams that describing the process of cathode polarization at all stages of the discharge.

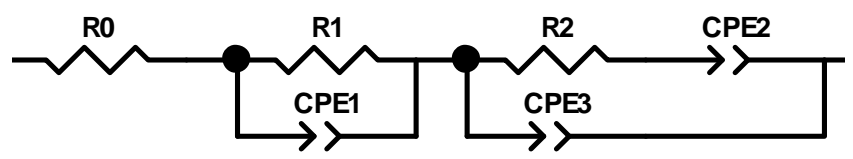

Fig. 4. Equivalent scheme used for fitting the Nyquist diagrams characterizing the process of $L i+$ ions intercalation into the LPS cathode based on nanodispersed rutile

This scheme for different values of its component characteristic parameters summarizes the combination of Voigt model and adsorption model $(0<x \leq 0.45)$ and Randle's model $(x \geq 0.55)$.

For the model flexibility increasing constant phase elements (CPE) were used at the equivalent scheme selection. Chain $R_{1}-C P E_{1}$ simulates the impedance of the $\mathrm{Li}^{+}$ions penetration through the $\mathrm{TiO}_{2} /$ electrolyte interface and their diffusion in the channels and pores of the material crystal structure for the entire range of the parameter $x$ variation. A type of elements connection (resistance and the Warburg element in parallel) corresponds to a semi-infinite diffusion in the spherical particles. Simultaneously with the intercalation of $\mathrm{Li}^{+}$ions in the cathode material their adsorption on the surface of rutile particles and the formation of double electric layer were carried out. This process is reflected at equivalent scheme by the chain $\left(R_{2}-C P E_{2}\right)-C P E_{3}$. Values of exponent indexes for $C P E_{2}$ and $C P E_{3}$ are in the range of $0.96-1.00$ so these elements have the physical contents of adsorption capacity and the capacity of surface double electric layer, respectively. The analysis of changes in the values of the equivalent schemes parameters for different intercalation degree was carried out. Diffusion coefficients of $\mathrm{Li}^{+}$ions (Fig. 5) were calculated as described in (Liu et al., 2008).

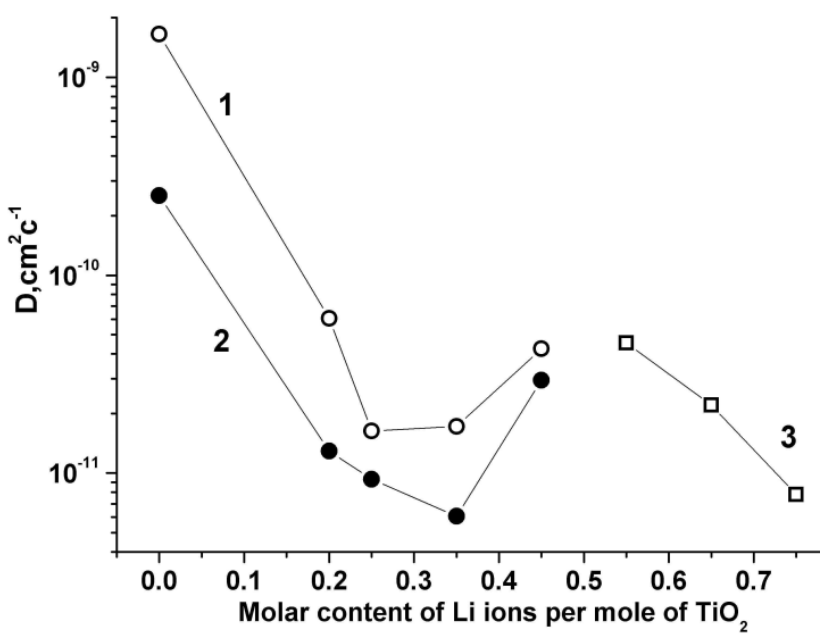

Fig. 5. The dependence of the diffusion coefficients of $L i^{+}$ions in the cathode material based on nanodispersed rutile on the degree of intercalation 
The presence of two kinetic processes with different time constants at the first stage of discharge was fixed. Calculated diffusion coefficient values decline up to $\mathrm{x}=0.3-0.35$ changing from $10^{-9}$ to $10^{-11} \mathrm{~cm}^{2} / \mathrm{s}$. Electric properties of cathode was homogenized at the range $0.35 \leq x \leq 0.45$ and with the increasing of the rate of charge transfer process. At the final stage $\mathrm{Li}^{+}$ions diffusion coefficient decreases from $7 \cdot 10^{-10}$ to $2 \cdot 10^{-11} \mathrm{~cm}^{2} / \mathrm{s}$.

\section{CONCLUSIONS}

The possibility of rutile nanoparticles specific surface area, crystallite size, degree of agglomeration control by ethanol molar content during $\mathrm{TiCl}_{4}$ hydrolysis in the hydrochloric acid-ethanol aqueous solution has been shown. It is found that the value of specific capacity of model lithium power sources with cathodes on the basis of the materials obtained depends on the size of individual particles of material and its agglomeration. The regularities of electrochemical intercalation of $\mathrm{Li}^{+}$in rutile nanoparticles have been studied, kinetics of the process analyzed, diffusion coefficients of the $\mathrm{Li}^{+}$ions calculated, the predominant role of the surface effects impact fixed.

The research described in this paper was supported by CRDF/USAID (grant UKX 2-9200-IF-08) and Ministry of Science and Education of Ukraine.

\section{REFERENCES}

[1] Hu Y.-S., Kienle L., Guo Y.-G., Maier J. High Lithium Electroactivity of Nanometer-Sized Rutile $\mathrm{TiO}_{2}$. Adv. Mater., 18 (2006), 1421-1426. doi: 10.1002/adma.200502723

[2] Liu S., Zhang J., Huang K., Yu J. Improvement of Electrochemical Performance of $\mathrm{LiMn}_{2} \mathrm{O}_{4}$ Composite Cathode by ox-MWCNT addition for Li-ion Battery. Braz. Chem. Soc., 19 (2008), 1078-1083. doi: 10.1590/S0103-50532008000600005

[3] Wang Y., Zhang L., Deng K., Chen X., Zou Z. Low Temperature Synthesis and Photocatalytic Activity of Rutile $\mathrm{TiO}_{2}$ Nanorod Superstructures. J. Phys. Chem., 111 (2007), 2709-2714. doi: 10.1021/jp066519k

Address: V.O. Kotsyubynsky, I.F. Myronyuk, V.L. Chelyadyn, V.V. Moklyak: Vasyl Stefanyk Precarpathian National University, 57, Shevchenko Str., Ivano - Frankivsk, 76025, Ukraine.

E-mail: v_kotsuybynsky@mail.ru; myrif@rambler.ru; chvl@email.ua; mvvmcv@mail.ru.

Received: 16.10.2013; revised: 03.02. 2014

Коцюбинський В.О., Миронюк І.Ф., Челядин В.А., Мокляк В.В. Синтез структура та електрохімічні властивості наностержнів рутилу. Журнал Прикарпатського університету імені Василя Стефаника, 1 (1) (2014), 27-32.

Наночастинки рутилу стержневидної морфології отримано методом гідролізу ТiCl4 3 застосуванням розчинів хлористоводневої кислоти та етилового спирту при температурі $40^{\circ} \mathrm{C}$. Встановлено, що величина питомої площі поверхні, розмір кристалітів, ступінь їх агломерації визначається молярним вмістом етанолу в реакційному середовищі. Отримані матеріали тестувадися в якості катодного матеріалу для літієвих джерел струму. Максимальне значення питомої ємності (250 мА·год/г ) при 
розряді в гальваностатичних умовах зафіксовано для випадку застосування матеріалу з максимальним ступенем агломерації та мінімальним розміром частинок. Простежено перебіг інтеркаляції іонів літію в катодний матеріал на основі наночастинок рутилу стержневидної морфології та визначено значення коефіцієнтів дифузії $\mathrm{Li}^{+}$на різних процесах.

Ключові слова: рутил, кристалічна структура, інтеркаляція іонів літію, імпедансна спектроскопія. 